\title{
Adaptation Challenges Faced by Pakistani University Entrants
}

\author{
Fareeha Javed \\ Lahore College for Women University, Pakistan
}

\begin{abstract}
This paper reports on a study conducted to explore the challenges faced by Pakistani university entrants in adapting to university culture. Several studies have been conducted on first-year experience and challenges faced by students in adaptation to university culture globally. However, this was the first study conducted on this topic in the Pakistani context. Key adaptation categories studied were: academic, social, linguistic, and environmental adaptation. The data was collected through a quantitative questionnaire dispensed to 180 first year undergraduate students enrolled in a public-sector university in Pakistan. The findings revealed that many of the adaptation challenges faced by the Pakistani university entrants in this study are similar to those in the Western contexts and other international settings. However, this study also found that some demands of the university culture pose bigger challenges to the Pakistani university entrants.
\end{abstract}

Keywords: First-year students; adaptation; Pakistan; undergraduate; international students.

\section{Introduction and Background}

The concept of first-year experience has gained notable attention in educational research owing to the rising concerns regarding difficulties faced by the university entrants in adapting to the university culture during the first year. According to Javed (2016), several researchers have found that challenges faced during the first year lead to an increase in the failure and drop-out rate (Gardner, 2013; Lowe \& Cook, 2003; Newman, 2016; Pascarella \& Terenzini, 1991; Tinto, 1993). In the light of earlier studies on this problem, it could be said that the university entrants in this study may also be facing various challenges to adapt to the new culture as each of them comes from a separate type of prior educational culture, and holds different beliefs and values. Javed (2016) notes that a number of studies have shown that, for many students, their first-year experience in university is not positive and students face many challenges in adapting to the new learning environment (Anderson, Wason, \& Southall, 2016; Baker, 2015; Bowlesa, Fisher, McPhailc, Rosenstreich, \& Dobsone, 2014; Chen, Morin, Parker, \& Marsh, 2015; Omachinski, 2014; Sevinç \& Gizir, 2014).

There has been extensive research on the topic of students' first-year experience in university over the last four decades. Although, the existing research has produced important findings on students' first-year experience, the research has been predominantly conducted in Western contexts, with a large number of studies emerging from Australia, the United Kingdom and the United States of America (Javed, 2016). To date, no study has been conducted on students' adaptation challenges during the first year in a Pakistani university context. This study therefore aimed to investigate the adaptation challenges faced by Pakistani university entrants. A further aim was to explore whether Pakistani university entrants in this study encountered the same adaptation challenges as documented in studies conducted in the Western contexts. 
This study is a part of a larger study conducted by the author for their Doctor of Philosophy program and as such this study has been previously reported as part of a finalised Doctor of Philosophy thesis (Javed, 2016).

\section{Adaptation}

According to Berry (1997), "Adaptation refers to changes that take place in individuals or groups in response to environmental demands" (p.13). However, "adaptation may or may not improve the "fit" between individuals and their environments" (Berry, 2005, p.709). Berry (1997) also maintains that "there are two main types of adaptation: psychological and sociocultural adaptation". Javed (2016) posits that "this idea can be applied to students' adaptation to university as they have to adapt at both the psychological and the sociocultural level" (p.20). The current study looked into the sociocultural adaptation of the Pakistani university entrants to the university culture.

\section{Categories of Adaptation}

Although university culture presents learners with a relatively complex environment to which they must adapt to be successful in university, there is significant consensus among researchers in regards to the framework of a broad adaptation to university culture (Credé \& Niehorster, 2012). Much of the research in the sphere of adaptation to university either relies explicitly on Baker and Siryk's (1984) theoretical taxonomy, or the constructs that constitute a subset of their taxonomy (Javed, 2016). Baker and Siryk based their taxonomy on a review of the literature on adaptation to university extant at that time and characterised university entrants' adaptation to university under four broad categories: academic adaptation (Baumgart \& Johnstone, 1977; Borow, 1947), social adaptation (Wright, 1973), personal-emotional adaptation (Kramer, 1980), and institutional attachment (Munro, 1981).

This study adopted two categories from Baker and Siryk's (1984) adaptation taxonomy: academic and social adaptation. These two categories were included in this study because they are the two major adaptations university entrants have to undergo. Moreover, these two categories have been widely included by the majority of researchers in their studies on adaptation to new learning culture (Buchanan, Ljungdahl, \& Maher, 2015). The reason for not selecting the personal-emotional adaptation (psychological adaptation) from Baker and Siryk's taxonomy is because this study focused on sociocultural adaptation only and did not look into learners' psychological adaptation. Furthermore, this study did not select Baker and Siryk's institutional attachment because it did not focus on studying learners' attachment to a particular insititution (Javed, 2016).

According to Javed (2016), Baker and Siryk (1984) contend that academic adaptation indicates the level to which learners have adapted to the university academic demands, as shown through their engagement or involvement with the course material; their attitudes towards their study course or program; and how adequate their academic and study efforts are. On the other hand, social adaptation indicates the extent to which learners are taking part in campus activities; have integrated into the social fabric of university residences as well as the broader university culture; meet new people and make friends; and cope with difficulties like missing their families or loneliness (Javed, 2016).

In the Pakistani university context, some social adaptation problems experienced by university entrants are of a different nature compared with those in the Western countries. For example, a significant problem for a majority of learners, can be that it is their first experience in a mixed gender institution. In the Pakistani education system, most learners have their school and college $^{1}$ education at a single-gender school or college where they are taught by teachers of the same gender. However, there are both female and male peers and teachers in universities. Social interaction with peers and teachers of opposite gender may present a big challenge to some university entrants, and they may find it difficult to adapt to a co-education culture (Javed, 2016).

In addition to academic and social adaptation, Javed (2016) notes that a number of researchers (Gemici, Lim, \& Karmel, 2013; Huang, 2012) have found that linguistic adaptation also holds great importance for successful adaptation to university. Although linguistic adaptation is an important factor, major research on the construct has been conducted mainly in native English speaking countries with focus on the linguistic adaptation of international students from non-English speaking countries (NESCs) or English as second language (ESL) background. There is a dearth of research on the linguistic adaptation of NESCs

\footnotetext{
${ }^{1}$ There are separate institutions for higher secondary education in Pakistan referred to as colleges.
} 
or ESL students' adaptation to English medium of instruction within a university setting in NESCs context. Along with academic and social adaptation, the students in this study were also required to integrate into the university linguistic culture to adapt to the university culture during the first year (Javed, 2016).

Yet another adaptation category is the environmental adaptation. University entrants' first reactions to and feelings towards the new environment, and the relationship they build with it during the early days on campus plays a critical role in their overall first-year experience (Kantanis, 1998; 2000). Nonetheless, it remains an under-researched area despite being an important factor regarding adaptation to university culture. This study perceived that environmental adaptation also holds great importance in the first-year experience. Hence, in this study, the adaptation to university construct included four adaptation categories: academic, social, linguistic, and environmental adaptation (Javed, 2016).

\section{Methodology}

A self-reporting questionnaire was developed in English language comprising a total of 43 items that gauged information on the repondents' academic, social, linguistic and environmental adaptation experiences during the first semester at university. The respondents were asked to report on the questionnaire items using a four-point Likert scale (1=Strongly Disagree; 2=Disagree; 3=Agree; and 4=Strongly Agree) to show their disagreement or agreement with the particular adaptation experiences. The traditional five-point Likert scale was not used in this study and instead the 4-point Likert scale was specifically adopted to avoid having any neutral midpoint as an option (Javed, 2016). The reason for not using a neutral option in the questionnaire was to encourage participants to make a definite choice and express both the direction and strength of their opinion about the questionnaire items instead of giving a neutral response or choosing an intermediate position on the scale. It thus helped minimise the possibility of respondent ambiguity across response categories as suggested by Beamish (2004).

The questionnaire respondents were 180 first year students at a public-sector university in Pakistan. The respondents belonged to four Bachelor of Studies (BS) Majors: Chemistry, Computer Science, Education, and English Literature. The 180 respondents therefore formed a naturally occurring sample because the enrolment in each of the four BS majors was 45. Data was collected three months after the start of the first semester. It was expected that, by that time, learners would be in a good position to share their adaptation challenges faced after university entrance.

The percentages of the responses to each item in each sub-section were then analysed to assist in finding out the percentage of respondents undergoing various adaptation experiences in all the four adaptation categories (sub-scales). The data was presented in separate tables for each adaptation category. Along with the data for all the four Likert scale points, dichotomous percentages for the two disagreement points (Combined disagreement) and two agreement points (Combined agreement) were also analysed for all the items in all the four adaptation categories. In addition, the Mean score for all the items was also analysed. The results and findings focused mainly on the combined dichotomous percentages to compare the difference between the distribution of responses in each adaptation category.

\section{Findings}

The results comprised both positive adaptation experiences and challenges faced during adaptation. Since the study was primarily aimed at investigating the challenges faced by the respondents in adapting to the university culture, findings related to the challenges in the four adaptation categories where more than $40 \%$ of students were experiencing the issues were focused and discussed only. The items revealing adaptation challenges have been shaded in the results tables.

Despite the majority of the study respondents reporting (Table 1) that they were finding the university academic tasks easier than those in college (item 1.1) and were adapting to the university academic culture (item 1.2), more than half of the respondents indicated that they needed extra help for completing their study tasks inside university hours (item 1.3). The respondents also reported the need to devote more time to their studies (item 1.6) and work harder than they used to do in college (item 1.7).

Academic failure is relatively common in higher education. Our own analysis of 2016-17 institutional data from a large, comprehensive Australian university showed that the incidence of academic failure varied across courses with roughly $40 \%$ of students failing one or more academic units during their degree. Importantly, academic failure contributed a four-fold increase 
to the risk of course attrition compared to students who did not fail a unit of study (Ajjawi, Dracup, Zacharias, Bennett, \& Boud, 2019). Approximately $70 \%$ of those who failed persisted with their studies, while $30 \%$ dropped out and $58 \%$ of those who failed one unit subsequently failed more. Academic failure is often attributed to multiple factors, which suggests that multiple strategies are required for successful course completion following a failure. Furthermore, the diversification of the student body including "the growing realities of non-linear student pathways, diverse student cohorts, and increasingly partial, part-time, deferred and liminal enrolment status" attunes us to the need for flexible and tailored/individualised support strategies (Harvey, Szalkowicz, \& Luckman, 2017, p. 7). Given that the majority of students, who fail do persist (Ajjawi et al., 2019), understanding the strategies they use to overcome academic failure might help us to better support students who fail, in all their diversity. In this paper, we examine the responses of students who fail and persist, to identify what drives them to continue, the support strategies they seek and how they adapt.

\section{Table 1}

Academic Adaptation Challenges

\begin{tabular}{|c|c|c|c|c|c|c|c|}
\hline Items & SDA & DA & $\mathbf{A}$ & SA & CDA & $\mathbf{C A}$ & Mean \\
\hline $\begin{array}{l}1.1 \mathrm{I} \text { am finding the university academic } \\
\text { tasks easier than those in college }\end{array}$ & 7.2 & 32.0 & 50.3 & 10.5 & 39.2 & 60.8 & 2.64 \\
\hline $\begin{array}{l}1.2 \mathrm{I} \text { am adapting to the university } \\
\text { academic culture }\end{array}$ & 7.2 & 9.8 & 75.8 & 7.2 & 17.0 & 83.0 & 2.83 \\
\hline $\begin{array}{l}1.3 \text { I need extra help for completing my } \\
\text { study tasks inside university hours }\end{array}$ & 7.1 & 35.1 & 29.2 & 28.6 & 42.2 & 57.8 & 2.79 \\
\hline $\begin{array}{l}1.4 \text { I need to take tuition for completing my } \\
\text { study tasks outside university hours }\end{array}$ & 33.1 & 45.5 & 17.5 & 3.9 & 78.6 & 21.4 & 1.92 \\
\hline $\begin{array}{l}1.5 \text { I can cope with the university teachers' } \\
\text { teaching style }\end{array}$ & 9.9 & 16.4 & 63.2 & 10.5 & 26.3 & 73.7 & 2.74 \\
\hline $\begin{array}{l}1.6 \text { I need to devote more time to my } \\
\text { studies in university than I used to do in } \\
\text { college }\end{array}$ & 9.7 & 28.8 & 39.9 & 21.6 & 38.5 & 61.5 & 2.73 \\
\hline $\begin{array}{l}1.7 \text { I need to work harder in university than } \\
\text { I used to do in college }\end{array}$ & 7.8 & 27.3 & 37.0 & 27.9 & 35.1 & 64.9 & 2.85 \\
\hline $\begin{array}{l}1.8 \text { I can manage the university academic } \\
\text { workload }\end{array}$ & 23.2 & 34.4 & 29.1 & 13.3 & 57.6 & 42.4 & 2.32 \\
\hline $\begin{array}{l}1.9 \text { I can complete my academic tasks } \\
\text { within given time }\end{array}$ & 5.3 & 19.1 & 55.3 & 20.4 & 24.4 & 75.7 & 2.91 \\
\hline $\begin{array}{l}1.10 \text { I feel shy to approach academic staff } \\
\text { when I need assistance in academic or } \\
\text { other tasks outside classroom }\end{array}$ & 4.6 & 16.4 & 69.1 & 9.9 & 21.0 & 79.0 & 2.84 \\
\hline $\begin{array}{l}1.11 \text { I do not hesitate to ask the teacher } \\
\text { questions in classroom }\end{array}$ & 11.0 & 33.2 & 34.4 & 21.4 & 44.2 & 55.8 & 2.66 \\
\hline $\begin{array}{l}1.12 \text { I do not hesitate to request the teacher } \\
\text { for clarification of a concept in classroom }\end{array}$ & 11.4 & 27.9 & 36.4 & 25.3 & 39.3 & 61.7 & 2.77 \\
\hline
\end{tabular}

Note: $\mathrm{SDA}$ = Strongly Disagree (1); DA = Disagree (2); A = Agree (3); SA = Strongly Agree (4); CDA = Combined Disagree; $\mathrm{CA}=$ Combined Agree 
Table 2

Social Adaptation Challenges

\begin{tabular}{|c|c|c|c|c|c|c|c|}
\hline Items & SDA & DA & $\mathbf{A}$ & $\mathbf{S A}$ & CDA & $\mathbf{C A}$ & Mean \\
\hline 2.1 I have made friends on campus & 5.2 & 8.4 & 59.7 & 26.6 & 13.6 & 86.3 & 3.08 \\
\hline 2.2 I feel shy to socialise with others on & 28.1 & 40.5 & 24.2 & 7.2 & 68.6 & 31.4 & 2.10 \\
\hline \multicolumn{8}{|l|}{ campus } \\
\hline 2.3 I like to socialise on campus & 9.9 & 20.5 & 50.3 & 19.3 & 30.4 & 69.6 & 2.79 \\
\hline $\begin{array}{l}2.4 \text { I feel shy to interact with the opposite gender } \\
\text { on campus }\end{array}$ & 26.0 & 27.9 & 30.5 & 15.6 & 53.9 & 46.1 & 2.36 \\
\hline 2.5 I feel isolated on campus & 26.4 & 39.9 & 23.6 & 10.1 & 66.3 & 33.7 & 2.18 \\
\hline $\begin{array}{l}2.6 \text { I like to participate in social activities on } \\
\text { campus }\end{array}$ & 8.2 & 29.7 & 46.6 & 15.5 & 37.9 & 62.1 & 2.70 \\
\hline $\begin{array}{l}2.7 \text { I have joined a society/club/association on } \\
\text { campus }\end{array}$ & 30.1 & 49.7 & 15.0 & 5.2 & 79.8 & 20.2 & 1.95 \\
\hline 2.8 I am adapting to the university social culture & 12.3 & 31.2 & 44.2 & 12.3 & 43.5 & 56.5 & 2.56 \\
\hline $\begin{array}{l}2.9 \text { It is easier to socialise in university as } \\
\text { compared to college }\end{array}$ & 17.5 & 30.5 & 39.7 & 12.3 & 48.0 & 52.0 & 2.57 \\
\hline
\end{tabular}

Note $: \mathrm{SDA}=$ Strongly Disagree; DA = Disagree; $\mathrm{A}=$ Agree; $\mathrm{SA}=$ Strongly Agree; $\mathrm{CDA}=$ Combined Disagree; $\mathrm{CA}=\mathrm{Combined}$ Agree; $\mathrm{M}=$ Mean

The results (Table 2) showed that although a large number of respondents reported that they like to socialise on campus (item 2.3), a noticeable number of respondents reported feeling shy to interact with the opposite gender on campus. Further finding s revealed that despite a large number of respondents showing their liking to participate in social activities (item 2.6), the majority of respondents showed disagreement at having joined a society/club/association on campus (item 2.7). In addition, a noticeable percentage of respondents reported that they were not adapting to the university social culture (item 2.8), and that it was not easier to socialise on campus compared to college (item 2.9).

A large number of respondents (Table 3) reported that they could not speak English fluently (3.5) and confidently (item 3.6). In addition, the majority of respondents were not confident presenting orally in English in front of an audience without the fear of making English language mistakes (item 3.8). The findings also showed that over half of the respondents showed agreement to the need to seek help (tuition/coaching) in learning and understanding English language (item 3.9). This finding contrasts to what the respondents reported to item 1.4 (I need to take tuition for completing my study tasks outside university hours) in the current study where the majority of respondents indicated that they did not need tuition for completing their study tasks outside university hours.

Moreover, a large number of respondents reported that they think in Urdu (official state language of Pakistan) and then translate in English before final reproduction of a response in English (item 3.10). 
Table 3

Linguistic Adaptation Challenges

\begin{tabular}{lcccc|ccc}
\hline Items & SDA & DA & A & SA & CDA & CA & Mean \\
\hline $\begin{array}{l}\text { 3.1 I can do critical reading for comprehending the } \\
\text { texts (in English) in my BS study syllabus }\end{array}$ & 9.9 & 29.1 & 55.0 & 6.0 & 39.0 & 61.0 & 2.57 \\
3.2 I can comprehend the lectures in English & 8.0 & 23.3 & 60.0 & 8.7 & 31.3 & 68.7 & 2.69 \\
3.3 I face no problem in writing assignments in & 8.6 & 20.4 & 55.9 & 15.1 & 29.0 & 71.0 & 2.78 \\
English & & & & & & & \\
3.4 I face no problem in taking assessments in & 8.6 & 20.4 & 55.3 & 15.7 & 29.0 & 71.0 & 2.78 \\
English & & & & & & & \\
3.5 I can speak English fluently & 14.9 & 48.1 & 31.8 & 5.2 & 63.0 & 37.0 & 2.27 \\
3.6 I can speak English confidently & 13.2 & 45.0 & 37.2 & 4.6 & 58.2 & 41.8 & 2.33 \\
3.7 I am adapting to the English language of & 2.6 & 22.4 & 60.5 & 14.5 & 25.0 & 75.0 & 2.87 \\
instruction in university & & & & & & & \\
\hline $\begin{array}{l}\text { 3.8 I can present orally in English in front of an } \\
\text { audience without the fear of making English } \\
\text { language mistakes }\end{array}$ & 20.4 & 40.1 & 29.6 & 9.9 & 60.5 & 39.5 & 2.29 \\
3.9 I have to take help (tuition/coaching) in learning \\
and understanding the English language
\end{tabular}

Note: $\mathrm{SDA}=$ Strongly Disagree; DA = Disagree; A = Agree; SA = Strongly Agree; CDA = Combined Disagree; CA = Combined Agree; $\mathrm{M}=$ Mean

The findings for environmental adaptation (Table 4) revealed that a noticeable number of respondents did not feel welcome during their initial days on campus (item 4.1). A little more than half of the respondents reported feeling shocked on their first day on campus on finding it different from college (item 4.2), and feeling nervous during the initial days on campus (item 4.3).

The majority of respondents felt that the university culture was different to that at school (item 4.4) and college (item 4.5). Lastly, a little more than half of the respondents agreed that they wanted to carry on with their old ways of learning during their university years (item 4.9) despite a substantive number of respondents showing willingness (item 4.8) to learn new ways to adapt to the new culture. 
Table 4

Environmental Adaptation Challenges

\begin{tabular}{|c|c|c|c|c|c|c|c|}
\hline Items & SDA & DA & $\mathbf{A}$ & $\mathbf{S A}$ & CDA & CA & Mean \\
\hline $\begin{array}{l}\text { 4.1 I felt welcome during my initial days on } \\
\text { campus }\end{array}$ & 18.3 & 26.1 & 47.8 & 7.8 & 44.4 & 55.6 & 2.54 \\
\hline $\begin{array}{l}4.2 \text { I was shocked on my first day on campus } \\
\text { on finding it different from college }\end{array}$ & 17.3 & 31.6 & 36.0 & 15.1 & 48.9 & 51.1 & 2.52 \\
\hline $\begin{array}{l}4.3 \text { I felt nervous during the initial days on } \\
\text { campus }\end{array}$ & 14.4 & 27.5 & 45.0 & 13.1 & 41.9 & 58.1 & 2.57 \\
\hline $\begin{array}{l}\text { 4.4 I feel no difference between university and } \\
\text { school culture }\end{array}$ & 43.8 & 46.4 & 3.3 & 6.5 & 90.2 & 9.8 & 1.73 \\
\hline $\begin{array}{l}4.5 \text { I feel no difference between university and } \\
\text { college culture }\end{array}$ & 40.8 & 44.7 & 8.6 & 5.9 & 85.5 & 14.5 & 1.80 \\
\hline $\begin{array}{l}\text { 4.6 I am finding it easy to adapt to university } \\
\text { culture }\end{array}$ & 15.1 & 22.4 & 51.3 & 11.2 & 37.5 & 62.5 & 2.59 \\
\hline 4.7 I am learning to adapt to university culture & 4.6 & 19.1 & 65.1 & 11.2 & 23.7 & 76.3 & 2.83 \\
\hline $\begin{array}{l}4.8 \text { I do not want to learn new ways to adapt } \\
\text { to university culture }\end{array}$ & 19.0 & 43.8 & 26.7 & 10.5 & 62.8 & 37.2 & 2.29 \\
\hline $\begin{array}{l}4.9 \text { I want to carry on with my old ways of } \\
\text { learning during my university years }\end{array}$ & 13.9 & 33.1 & 43.7 & 9.3 & 47.0 & 53.0 & 2.48 \\
\hline 4.10 I like being at university & 4.6 & 11.3 & 63.6 & 20.5 & 15.9 & 84.1 & 3.00 \\
\hline $\begin{array}{l}\text { 4.11 University life has increased my } \\
\text { confidence }\end{array}$ & 3.3 & 6.7 & 51.3 & 38.7 & 10.0 & 90.0 & 3.25 \\
\hline $\begin{array}{l}\text { 4.12 University life makes me feel } \\
\text { independent }\end{array}$ & 6.7 & 11.9 & 52.3 & 29.1 & 18.6 & 81.4 & 3.03 \\
\hline
\end{tabular}

Note $:$ SDA = Strongly Disagree; DA = Disagree; A = Agree; SA = Strongly Agree; CDA = Combined Disagree; CA = Combined Agree; $\mathrm{M}=$ Mean

\section{Discussion}

The overall findings show that Pakistani university entrants encounter similar adaptation challenges as reported in studies conducted in the Western as well as other international contexts. Regarding academic adaptation, the university entrants' need to accept extra help to complete study tasks inside university hours in the current study is similar to Sheridan and Dunne's (2012) findings who studied a group of Irish first year undergraduate students and reported that this situation occurs because of the students' habit of being accustomed to directed learning with a great dependence on teachers at school and college. Similarly, the current study respondents' need to devote more time to studies at university compared to school and college coincides with that of a student engagement survey conducted by Cengage Learning India (Strang, 2015) which indicated that the majority of Indian university entrants found difficulty in managing time (53\%). Additionally, these students experienced a difference in managing time during pre-university years and at university, and the need to adopt new time management skills at university. The current study respondents also appeared to want to follow the same study habits that they used to have at school and college.

Another finding pertaining to academic challenges was that university entrants found the university workload to be heavier than the academic workload at school and college, which is a common challenge faced by university entrants internationally as well as in Pakistan. This is mainly because university academic culture is different to school and college, comprising different types of academic tasks from those they have undertaken previously. This finding is consistent with Asmar, Brew, McCulloch, Peseta and Berrie's (2000) examination of the first-year experience of Australian students at the University of Sydney, Australia who found that, along with other challenges, $33.4 \%$ of the study respondents expressed having a heavy workload at university. The percentage of respondents finding it hard to manage their university academic workload in the current study was significantly higher (57.6\%) compared to Asmar et al.'s study (33.3\%). 
The current study respondents' shyness during interaction with academic staff could increase their problems to adapt to the university academic culture and may create ongoing academic challenges during their university years. Similar arguments have been documented by Tinto (1993) regarding the importance of developing interactions with the academic staff in university and its role in successful transition.

A noticeable number of respondents reported feeling isolated on campus. This could be attributed to the reason that often students have close knit friendships at school and college where students from the same areas and backgrounds attend the same school and college; have easy access to academic staff; and have a supportive environment compared to university. On the contrary, university is a very big place where students from diverse educational, demographic, geographical (both urban and rural), and language backgrounds with varied prior experiences and beliefs come to study. Initially, many students may feel lost in a sea of people whom they don't know. Shyness adds to the challenge and students may feel isolated, alienated and rejected. Some previous studies have also reported that learners' failure to engage in social networks in the new setting may lead to problems like disengagement and isolation. Sevinç and Gizir (2014) undertook a qualitative study of 25 first year students (at Mersin University, Turkey) who were experiencing academic and social adjustment problems. The authors found that there were a number of factors that were negatively affecting those students' social adaptation. The factors included shyness, homesickness, loneliness, fear of disapproval by peers, participation in social/recreational activities, and management of leisure time. The current study respondents also reported feeling hesitant to socialise with others and interact with the opposite gender, and having lack of interest in participation in social activities on campus.

A large number of respondents indicated that they could not speak English fluently and confidently and these issues could be indicative of their hesitation and difficulties in making oral presentations in English. These challenges may lead to a number of academic adjustment problems in university. A possible reason for respondents facing problems in speaking English fluently and confidently could be that little attention is paid to developing English speaking skills in Pakistani schools, with a greater focus given to developing the other three skills (reading, listening and writing) as reported by Rahman (2002) and Shamim (2008; 2011). Similar problems were reported by Huang (2012) who studied Taiwanese university entrants and found that low proficiency in English language can lead students to feel hesitant when posing questions or replying to a lecturer's question in English, and showing unwillingness to participate in class discussion. The academic and linguistic issues of respondents in the current study could also have similar outcomes for students as can be seen in the problems faced by them in making oral presentations in English.

The finding regarding the respondents' habit of thinking in Urdu before final reproduction of a response in English reflects other findings in the linguistic adaptation category in this study which found that a large number of respondents could not speak English fluently and confidently. Naturally, thinking in Urdu and then translating in English may negatively impact fluency and confidence to speak English. Ahmed (2012) conducted a research on the English language learning situation in Pakistan. He also reports that the biggest challenge faced by ESL students is the positive transfer of thoughts and ideas from first language (Urdu in this case) into second language (English).

With regard to environmental adaptation, feeling unwelcome, shocked and nervous during the initial days at a new place may be a natural and usual experience for many individuals entering a new culture. This was also evidenced in the case of Pakistani university entrants in the current study who found the university culture different from school and college cultures. Berry (1997) also reports that it is usual for someone to have these kinds of experiences when they are exposed to a new culture.

Although there are many issues that contribute to learners' feelings of nervousness and shock during the first few weeks or months at university, the mismatch between learners' expectations and issues in relation to the new environment is a significant concern in this study. Being different, compared to school and college, the university culture and its demands present university entrants with a plethora of challenges, and hence that can make it harder for the students to adapt to the university culture. A number of researchers (Briggs, Clark, \& Hall, 2012; Brinkworth, McCann, Matthews, \& Nordstrom, 2009) have found that the mismatch between the students' pre-university aspirations and the reality of their first year at university creates difficulty for university entrants to adapt to university culture.

\section{Conclusion}

The findings revealed that the academic adaptation challenges faced by the university entrants in the current study may be similar to those faced by university entrants not only in the Western countries but in other international contexts as well. However, the Pakistani university entrants may have greater challenges when adapting to the university academic culture 
compared to the university entrants in some Western countries, particularly the native English speaking countries. The reason lies in the fact that students in English speaking countries learn English as a first language. In contrast, being in a NESC, Pakistani students learn English as a second language. It can be seen in this study that university entrants faced language-related challenges along with other difficulties, especially when adapting to the demands of a second language such as English language of instruction in this case. The present study's findings showed that many students appeared to be struggling to meet the linguistic demands of the university academic culture due to their low level of English language knowledge and oral proficiency mainly due to having learnt English as a second language.

As far as the social adaptation experience of the Pakistani university entrants in this study is concerned, respondents indicated they were finding it more challenging to adapt to the university social culture compared to their Western counterparts. One of the reasons for this could be attributed to the shyness encountered when interacting with the opposite gender on campus as for the majority of the university entrants in Pakistan, university is their first experience in a mixed gender learning environment.

Another reason for university entrants in this study facing significant adaptation challenges may be due to the lack of a bridge between higher secondary institutions and universities in Pakistan. Some other factors may arise from the education policy for English language teaching and school and college system in Pakistan. The dual education policy in the secondary and higher secondary education system (Urdu medium of instruction for public sector schools and English medium of instruction for private sector schools) against a uniform policy in university education (English medium of instruction only) appears to be a reason leading to adaptation difficulties for university entrants who may have hailed from the public-sector Urdu medium of instruction schools and low status English medium schools.

Learning the culture of the new educational environment is one of the main requirements for the successful first-year experience. However, the university entrants in the current study reported reluctance to take this step (despite showing willingness to learn new ways to adapt to university culture) which may have presented them with further problems in adaptation to the new learning environment.

\section{References}

Ahmed, I. (2012). Investigating Students' Experiences of Learning English as a Second Language at the University of Sindh, Jamshoro, Pakistan. (Doctoral dissertation) University of Sussex, Brighton, United Kingdom. Retrieved from http://sro.sussex.ac.uk/id/eprint/48752

Anderson, D., Wason, H., \& Southall, J. (2016). Supporting business students' transition into higher education: The case of marketing downloads. Teaching in Higher Education, 21(8), 978-989. https://doi.org/10.1080/13562517.2016.1207625

Asmar, C. Brew, A. McCulloch, M., Peseta, T., \& Barrie, S. (2000). Report on the first year experience. Retrieved from https://sydney.edu.au/education-portfolio/ei/pastprojects/fye/research/pdfs/ITL_FYE_rpt.pdf

Baker, R., \& Siryk, B. (1984). Measuring adjustment to college. Journal of Counseling Psychology, 31(2), $179-189$. https://psycnet.apa.org/doi/10.1037/0022-0167.31.2.179

Baker, S. (2015). Students' writing 'in transition' from A-levels to university: how assessment drives students' understandings, practices and discourses. Assessment \& Evaluation in Higher Education, 1-19. https://doi.org/10.1080/02602938.2015.1082174

Baumgart, N. L., \& Johnstone, J. N. (1977). Attrition at an Australian university: A case study. The Journal of Higher Education, 48(5), 553-570. https://doi.org/10.1080/00221546.1977.11776574

Beamish, W. (2004). Consensus about program quality: An Australian study in early childhood education. (Doctoral dissertation) Griffith University, Brisbane, Australia. Retrieved from https://www120.secure.griffith.edu.au/rch/file/75b725a0-3620-5e04-a2e6-9019e9300f14/1/Beamish_2004_01Thesis.pdf

Berry, J. W. (1997). Immigration, acculturation, and adaptation. Applied Psychology: An International Review, $46(1), 5-68$. https://doi.org/10.1111/j.1464-0597.1997.tb01087.x

Berry, J. W. (2005). Acculturation: Living successfully in two cultures. International Journal of Intercultural Relations, 29(6), 697-712. https://psycnet.apa.org/doi/10.1016/j.ijintrel.2005.07.013

Borow, H. (1947). The measurement of academic adjustment. Journal of the American Association of Collegiate Registrars, 22(2), 274-286. 
Bowlesa, A., Fisher, R., McPhail, R., Rosenstreich, D., \& Dobson, A. (2014). Staying the distance: Students' perceptions of enablers of transition to higher education. Higher Education Research and Development, 33(2), 212-225. http://doi.10.1080/07294360.2013.832157

Briggs, A. R., Clark, J., \& Hall, I. (2012). Building bridges: understanding student transition to university. Quality in Higher Education, 18(1), 3-21. https://doi.org/10.1080/13538322.2011.614468

Brinkworth, R., McCann, B. Matthews, C., \& Nordstrom, K. (2009). First year expectations and experiences: student and teacher perspectives. Higher Education, 58(2), 157-173. http://doi.10.1007/s10734-008-9188-3

Buchanan, J., Ljungdahl, L., \& Maher, D. (2015). On the borders: adjusting to academic, social and cultural practices at an Australian university. Teacher Development, 19(3), 294-310. https://doi.org/10.1080/13664530.2015.1023462

Chen, X., Morin, A. S., Parker, P. D., \& Marsh, H. W. (2015). Developmental investigation of the domain-specific nature of the life satisfaction construct across the post-school transition. Developmental Psychology, 51(8), 1074-1085. https://psycnet.apa.org/doi/10.1037/a0039477

Credé, M., \& Niehorster, S. (2012). Adjustment to college as measured by the student adaptation to college questionnaire: A quantitative review of its structure and relationships with correlates and consequences. Educational Psychology Review, 24(1), 133-165. http://dx.doi.org/10.1007/s10648-011-9184-5

Gardner, A.F. (2013). Predicting community college student success by participation in a first year experience course. (Doctoral dissertation) Western Carolina University, Cullowhee, USA. Retrieved from https://libres.uncg.edu/ir/wcu/f/Gardner2013.pdf

Gemici, S., Lim, P., \& Karmel, T. (2013). The Impact of Schools on Young People's Transition to University. Longitudinal Surveys of Australian Youth. Research Report 61. Retrieved from https://www.lsay.edu.au/publications/search-for-lsaypublications/2541

Huang, Y.P. (2012). Design and implementation of English-medium courses in higher education in Taiwan: A qualitative case study. English Teaching \& Learning, 36(1), 1-51. http://dx.doi.org/10.6330/ETL.2012.36.1.04

Javed, F. (2016). Pakistani Learners' Transition into University. (Doctoral dissertation), Massey University, Palmerston North, New Zealand. Retrieved from http://hdl.handle.net/10179/11442

Kantanis, S. T. (1998). The role of program cohesion in effecting a smooth transition from secondary school to university. Paper presented at the Third Pacific Rim Conference on the First Year in Higher Education, Auckland, New Zealand.

Kantanis, S.T. (2000). The role of social transition in students' adjustment to the first-year of university. Journal of Institutional Research, 9(1), 100-110. Retrieved from http://www.aair.org.au/app/webroot/media/pdf/JIR/Journal\%20of\%20Institutional\%20Research\%20in\%20Australasia\%2 0and\%20JIR/Volume\%209,\%20No.\%201\%20May\%202000/Kantanis.pdf

Kramer, H. C. (1980). Monitoring freshman perceptions of college. Journal of the National Association for Women Deans, Administrators, and Counselors, 44(1), 7-13.

Lowe, H. \& Cook, A. (2003). Mind the gap, are students prepared for higher education? Journal of Further and Higher Education, 27(1), 149-152. https://doi.org/10.1080/03098770305629

Munro, B. H. (1981). Dropouts from higher education: Path analysis of a national sample. American Educational Research Journal, 18(2), 133-141. https://doi.org/10.3102\%2F00028312018002133

Newman, J.F. (2016). A First-Year Experience Course and its Relationship to Retention and Academic Success at a Public Community College. (Doctoral dissertation), East Tennessee State University, Johnson City, USA. Retrieved from https://dc.etsu.edu/cgi/viewcontent.cgi?article=4559\&context=etd

Omachinski, K. (2014). The Transition to College: an Acculturation Comparison of Domestic and International Students. (Doctoral dissertation). University of Wisconsin-Milwaukee, Milwaukee, USA. Retrieved from http://citeseerx.ist.psu.edu/viewdoc/download?doi=10.1.1.890.5412\&rep=rep1\&type=pdf

Pascarella, E. T., \& Terenzini, P. T. (1991). How college affects students: Findings and insights from twenty years of research. San Francisco: Jossey-Bass Publishers.

Rahman, T. (2002). Language, ideology and power: Language-learning among the Muslims of Pakistan and North India. Karachi: Oxford University Press.

Sevinç, S., \& Gizir, C. A. (2014). Factors Negatively Affecting University Adjustment from the Views of First-Year University Students: The Case of Mersin University. Educational Sciences: Theory and Practice, 14(4), $1301-1308$. http://DOI:10.12738/estp.2014.4.2081

Shamim, F. (2008). Trends, issues and challenges in English language education in Pakistan. Asia Pacific Journal of Education, 28(3), 235-249. https://doi.org/10.1080/02188790802267324

Shamim, F. (2011). Paper 14. In C. Hywel (Ed.), Dreams and realities: Developing countries and the English language. London: British Council. Retrieved from https://www.teachingenglish.org.uk/sites/teacheng/files/Z413\%20EDB\%20Section14.pdf

Sheridan, V., \& Dunne, S. (2012). The bigger picture: Undergraduate voices reflecting on academic transition in an Irish university. Innovation in Education and Teaching International, 49(3), 237-247. doi:10.1080/14703297.2012.703019 
Strang, T. (2015). Effects of College Life on Students' Time-Management Skills. Cengage Learning India. Retrieved from http://blog.cengage.com/effects-of-college-life-on-students-time-management-skills/

Tinto, V. (1993). Leaving the college: Rethinking the causes and cures of student attrition. Chicago: University of Chicago Press.

Wright, E. O. (1973). A study of student leaves of absence. Journal of Higher Education, 44, 235-247.

\section{Please cite this article as:}

Javed, F. (2019). Adaptation challenges faced by Pakistani university entrants. Student Success, 11(2), 41-51.

https://doi.org/10.5204/ssj.v11i3.1164

This article has been peer reviewed and accepted for publication in Student Success. Please see the Editorial Policies under the 'About' section of the Journal website for further information.

Student Success: A journal exploring the experiences of students in tertiary education

(c) (i) Except where otherwise noted, content in this journal is licensed under a Creative Commons Attribution 4.0 International Licence. As an open access journal, articles are free to use with proper attribution. ISSN: 2205-0795 